\title{
ELABORATING IMAGES THROUGH TEXT IN THE CODEX TELLERIANO-REMENSIS
}

\author{
By Christina Samons
}

After the Spanish conquest of the Americas in the fifteenth century, wealthy Spaniards commissioned the creation of groups of manuscripts called codices that documented indigenous ways of life in minute detail, from specific descriptions of counting systems and the storage of grain to extensive dynastic histories. Although the length, form, and purpose of these post-Conquest codices vary depending on their commissioner, they relied on the handiwork of mestizo scribes called tlacuilos who were able to negotiate between the preConquest and post-Conquest worlds that they simultaneously inhabited. ${ }^{1}$ The Codex Telleriano-Remensis is one such object.

Although the exact date of origin of the Codex Telleriano-Remensis is unknown, scholars have determined that it was created in the mid-sixteenth century, less than one hundred years after the conquest of Latin America by Spain. The codex contains three sections: a ritual calendar, a divinatory manuscript, and a historical account of nearly three decades of Mexican history, including and leading up to the four decades following the Spanish conquest. 2

\footnotetext{
${ }^{1}$ Mestizo refers to an individual who is possesses both indigenous and Spanish blood.

${ }^{2}$ Eloise Quiñones Keber, Codex Telleriano-Remensis: Ritual, Divination, and History in a Pictorial Aztec Manuscript. (Austin: University of Texas Press, 1995), 122.
} 
In this paper I will be examining The Image from folio $29 \mathrm{~V}$ (Fig. 1), taken from the third section of the Codex Telleriano-Remensis, which contains a pictorial history of the dynastic lineages of the Aztec empire. ${ }^{3}$ This specific image provides an account of pre-Hispanic Aztec history that is mediated by the incorporation of written Spanish language in conjunction with The Images themselves. The Spanish written text, which annotates the pre-Hispanic images in Folio 29V of the Codex Telleriano-Remensis, presents an interpretation of historical events that served to legitimize Spanish rule over political and social affairs in Colonial Latin America.

The painted images in Folio $29 \mathrm{~V}$ simultaneously depict the death of Acamapichtli, a ruler of the Aztecs, and the subsequent election of his son, Huitzilihuitl, who is considered to be the first ruler of the Aztec dynastic empire. Latin American scholar Eloise Quiñones Keber describes The Image

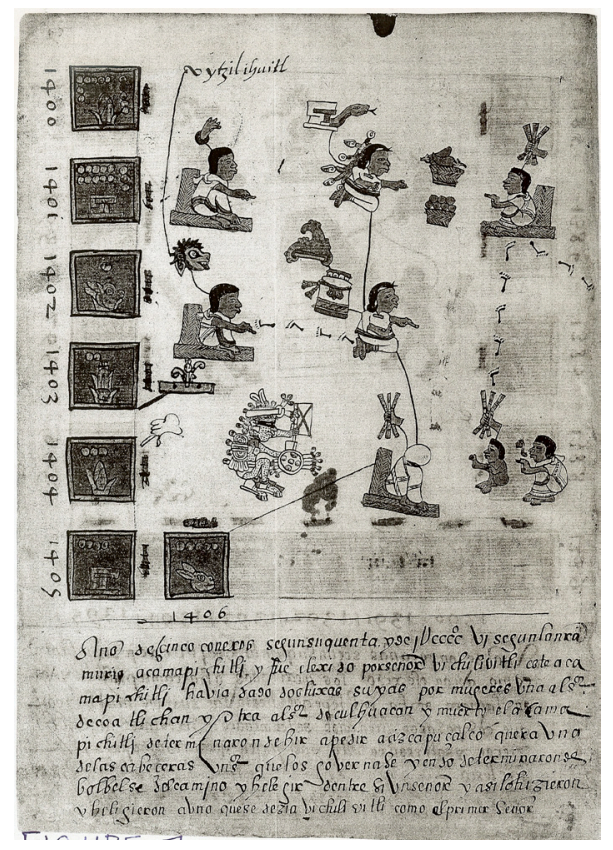

Fig. 1: Artist Unknown. Folio 29v. (Photocopy from Eloise Quiñones Keber, Codex Telleriano-Remensis: ritual, divination, and history in a pictorial Aztec manuscript. Austin: University of Texas Press, 1995.) Ink and paint on European paper. 1549-1563.

${ }^{3}$ Ibid., 121. 
as significant for "showing the dynastic alliances that played a role in early successes of the Aztecs" and paved the way for their domination of the region. ${ }^{4}$ Dates for these events are provided on the left side of the page and utilize the pre-Hispanic method of counting days in groups of thirteen (trecena), represented by colored circles within the square year-markers. The Spanish text at the bottom of the page describes in words the historical narrative of The Images presented above in order to explain The Images to a Spanish reader.

Though a small group of pre-Hispanic codices have survived to this day, most were destroyed by the Spaniards who viewed them as a product of an uncivilized and pagan culture. ${ }^{5}$ The destroyed pre-Hispanic codices were soon replaced by codices commissioned by the Spaniards. The illustrators of these new codices still utilized conventional pre-Hispanic forms of representation but also modified the traditional images in order to adapt them to Spanish ideology. Therefore, most post-Conquest codices still in existence are hybrid objects, reflecting the preservation of indigenous cultural forms and values, despite the imposition of Spanish culture into the indigenous culture. However, when considering Folio $29 \mathrm{~V}$ as a "hybrid" image, it is important that one does not solely delineate which aspects of The Image are characteristic of a pre-Hispanic culture and which aspects are identifiable within the vein of a Western European artistic tradition. The hybrid nature of codices like the Codex Telleriano-Remensis should not be viewed in terms of a homogenized "European form" set "in opposition to similarly homogenized non-European conventions,"6 as art historians Carolyn Dean and Dana Liebsohn warn against. Instead of searching for perceived representative forms which inherently mark cultural differences within a pictorial space, close analysis of Spanish commissioned codices should focus on highlighting points of cultural continuity in representational forms and techniques over time and how representational forms are altered and adapted by the dominant culture.

Pre-Hispanic conventions are asserted in the Codex Telleriano-Remensis through both the artist's representation of human forms as well as the types of images painted throughout the codex. The artist of the Codex TellerianoRemensis was an indigenous Aztec scribe who modeled his images after other

\footnotetext{
${ }^{4}$ Ibid., 212.

${ }^{5}$ Gauvin Alexander Bailer, Art of Colonial Latin America, (London: Phaidon Press, 2005), 77.

${ }^{6}$ Carolyn Dean and Dana Leibsohn, "Hybridity and its Discontents: Considering Visual Culture in Colonial Spanish America," Colonial Latin American Review 12, no.1 (June 2003): 6.
} 


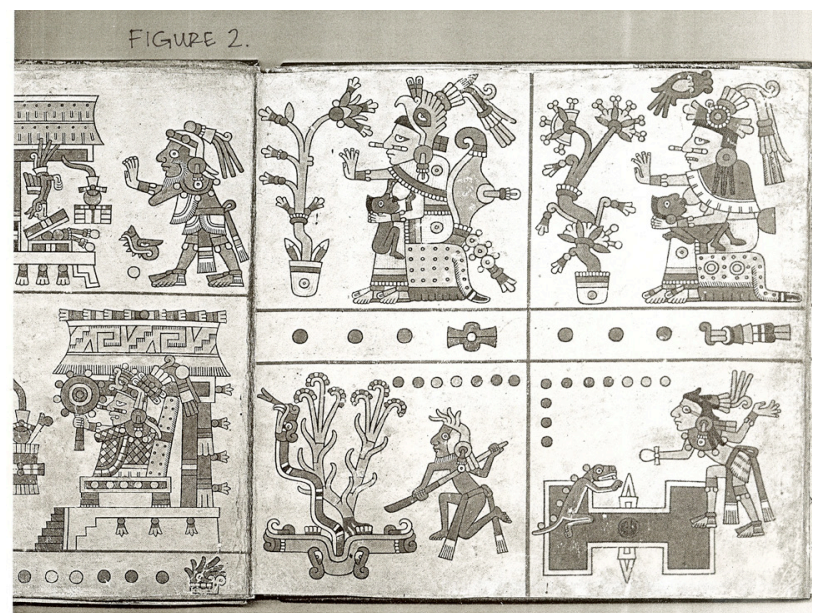

Fig. 2: Panel from the Codex Féjerváry-Mayer. (Photocopy from Codex Fejérváry-Mayer M 12014. Introduction by C. A. Burland. Graz: Akademische Druck- u. Verlagsanstalt, 1971.)

pre-Hispanic codices, such as the Codex Féjerváry-Mayer of the Borgia Group (Fig. 2). ${ }^{7}$ Following the tradition of pre-Hispanic pictorial conventions, the artist was not preoccupied with portraying human figures in geometrically accurate perspective nor was he concerned with grounding them within delineated pictorial space. Instead, the artist flattened bodies and applied paint in blocks of solid colors inscribed within bold figural outlines. In addition, rather than individualize persons with expression or other defining characteristics, pre-Hispanic codices identify people by their relationship to pictorial symbols or glyphs. ${ }^{8}$ Glyphs were able to communicate meaning solely through complex symbolic associations that had been standardized through numerous depictions by indigenous artists over time. Aztec scribes had an extensive knowledge of glyphic symbols and their significances, because the same symbolic markers were used in different pre-Hispanic codices to represent important common figures such as deities or rulers. As Quiñones Keber notes,

${ }^{7}$ Quiñones Keber, 109.

${ }^{8}$ C.A. Burland, introduction to Codex Fejérváry-Mayer M 12014 (Graz, Austria: Akademische Druck-u. Verlagsanstalt 1971), 28. 
"Because they were intended to convey so much information, pre-Hispanic images must be 'read' rather than just looked at." In the case of the Codex Telleriano-Remensis, the human figures in Folio 29v are identified primarily by characteristic glyphs denoting individuality that accompany each figure and are linked to that figure, both pictorially through the use of line and associatively through the knowledge of specific personal glyphs of Aztec scribes.

In addition to the indigenous figural representation, the Codex Telleriano-Remensis also utilizes representational techniques that have their origin in a written system of language based on the Roman alphabet. The introduction of written text into the Codex Telleriano-Remensis was completed much later than the completion of the original document by three mestizo annotators who were unrelated to the creator of the colored images. ${ }^{10}$ The fact that the textual annotations were completed later than the initial images is important to note, since prior to the arrival of the Spaniards in modern-day Mexico, the Aztec language of Nahuatl was an exclusively oral language. When the Spanish arrived, however, they not only brought with them new technologies, diseases, and Christianity, but also a writing system that was used to transliterate the Nahuatl language so that it could be understood by a larger Spanish population. ${ }^{11}$ The scribe who annotated the Codex Telleriano-Remensis included Nahuatl words written using the Roman alphabet, which would be recognizable to the Western world, in order to "convert" The Images into a form that could be understood and then used by the conquering Spaniards and future generations of Spaniards. In doing so, the Spanish not only hoped to increase their understanding of the existing indigenous cultures, but also to redefine them in terms that accorded with their own conceptions of time and history.

One way in which text is introduced into the Codex Telleriano-Remensis is through the imposition of numerical dates into the space of the composition that attempt to correspond with the dates provided by the Aztec trecena calendar system for the historical event portrayed. ${ }^{12}$ These added numbers have the effect of translating the dates from the Aztec calendar to the Roman-

\footnotetext{
${ }^{9}$ Quiñones Keber, 124.

${ }^{10}$ Jose Rabasa, "The Colonial Divide," Journal of Medieval and Early Modern Studies 37, no. 3 (2007): 515.

${ }^{11}$ Thomas Cummins, "From Truth to Lies: Colonial Ekphrasis and the Cross-cultural Translation," in Reframing the Renaissance, ed. Claire Farago, 153-174 (New Haven: Yale University Press, 1995), 156.

${ }^{12}$ Quiñones Keber, 175.
} 
based calendar system used in Europe. Preliminary dates had been written to the right of the square date markers but were later crossed out and replaced by more accurate dates on the left side of the folio. One explanation for the annotators' concern with accurate dating of the events depicted is a religious one, in that they wanted to seamlessly position Aztec dynastic history within the conception of linear time based on the life of Jesus Christ. Jose Rabasa notes that by reducing the two seemingly incompatible historical timelines of the Native Amerindians and the Christian Spaniards, the annotator of the Codex Telleriano-Remensis effectively achieves a "flattening of their [Native] past into homogeneous time" because "they assumed that the history of people... who have been recently incorporated into Christianity can be written by ascribing events anterior to the beginning of history [of Christ] with historical significance." ${ }^{13}$ The Spaniards' concern with finding an accurate date in the Codex Telleriano-Remensis shows that they desired to provide the "true" or correct Christian date of the Aztec events presented in accordance with their own worldview. They did not want to completely disregard or invalidate indigenous history but instead conformed indigenous culture and history with Spanish history as an attempt to legitimize their position of power in Latin America by appealing to both parties. Rabasa's observation supports art historian Thomas Cummins' discussion of the importance in mestizo artwork for the creation of one "truth" that could be accepted accurate as by both the indigenous Amerindians and the Spanish conquerors. The search for a common truth premised on the idea that "historical knowledge is possible in both cultures so that what... [is] written is true [emphasis added] even though the cultural relationship between symbols and their meaning may be different." ${ }^{14}$ Although the numerical symbols of Aztec writing and Latin script are different, their juxtaposition creates a common temporal space within which both pre-Hispanic and Hispanic accounts of history and time can coexist.

Reading The Images and text in Folio 29v further reveals that "accurate" dated years on the left of The Image are then linked with the human figures on multiple representational levels. Certain years are linked directly with figures by a single painted line that acts as a connector between the two and implies that a specific historical event occurred to the designated human subject dur-

\footnotetext{
${ }^{13}$ Rabasa, 526.

${ }^{14}$ Cummins, 164.
} 
ing the designated year. Additionally, the close proximity of text and image next to each other within a single page conveys to the reader that they are related concepts. The dynastic chronology is suggested through implied vertical registers created by the year markers on the left and that extend to the right of the folio. Even though The Images do not correspond exactly with events occurring within that year, such as in a timeline, the association of figures with a certain linear chronology through their positioning within the space of the page creates the effect of a continuous progression of time and, therefore, of continuous political and religious rule. The technique of conveying relationships associatively between distinct images on one page or panel in pre-Hispanic codices was not used. For example, each section of images in the Codex Féjerváry-Mayer (Fig. 2) is self-contained in that it presents one scene or deity, but the relationship of each of the four sections to each other within the space of the page is irrelevant, if not non-existent. ${ }^{15}$ Therefore, the relationship between numerical dates and The Images in Folio $29 \mathrm{~V}$ foregrounds the shift from pre-Hispanic temporal representation to one that relies on associative links between images and text introduced by the Spaniards.

The explanatory Spanish text at the bottom of the page is another intervention of written language into the narrative of The Images. The text reinforces the story told by The Images by telling of Huitzilihuitl's election following the death of his father. ${ }^{16}$ Although, on one hand, the addition of this paragraph acts solely as a means of conveying a historical narrative to a broader audience, the text also works to shape future interpretations of Folio 29v. Unlike pre-Hispanic codices, in which the meaning of images was bound up in symbolic representation through glyphs that are incorporated into The Image itself, scribes writing after the conquest of the Americas increasingly began to utilize textual annotations to externally provide the context for interpreting specific images. Furthermore, the novel-like composition of narrative paragraphs on each page on the history of Mexico is reinforced by the shift from the accordion format of the Codex Féjerváry-Mayer to bound pages resembling a modern-day book. Pre-Hispanic codices were not formatted into books read from left to right, but in accordion-like screen folds with images on both the

\footnotetext{
15 Burland, 28.

${ }^{16}$ Quiñones Keber, 122.
} 
recto and verso sides of the object. ${ }^{17}$ The Codex Telleriano-Remensis was painted and annotated by indigenous or mestizo authors, but the book itself was printed on European paper and its material composition contributes to the implicit reliance on European writing conventions that underlies this image.

Though more overtly used for a religious than a historical function, the Rhetorica Christiana, written by Friar Diego de Valadés, exemplifies a relationship between image and text that is analogous to the Codex Telleriano-Remensis. Both objects attempt to conjoin the Native and European conceptions of history through the mediation of written language as translated from one "language system," for example, that of the Aztecs, to Latin text. The text that accompanies and explains The Image helps to render it as a mnemonic device that aids memorization of Christian principles and themes. One image printed in the Rhetorica portrays the floor plan of a typical church in New Spain at a three-quarters "bird's eye" view (Fig.3). The walls of the church

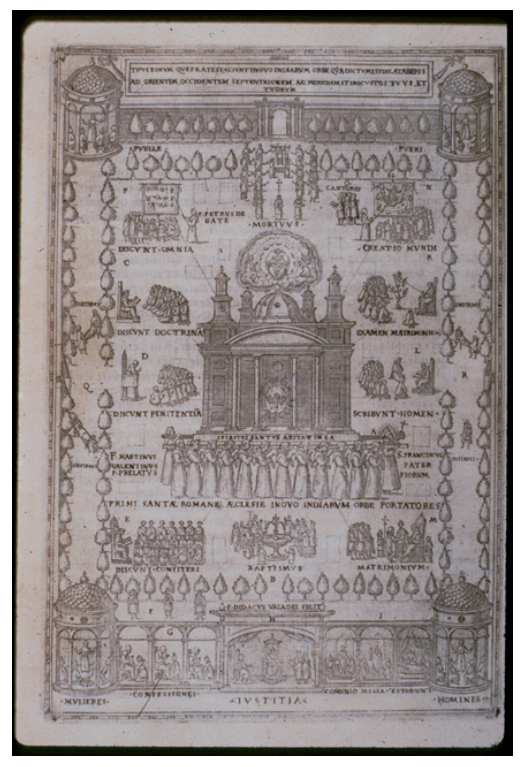

Fig 3: Diego de Valades. "Ideal Representations of the Franciscan Mission in Mexico." (Photocopy from Diego de Valades, Rhetorica Christiana, Perugia: apud Petrumiacobum Petrutium, 1579, 107.)

${ }^{17}$ Burland, 27. 
double as a border for the page that serves to inscribe the scenes and objects portrayed within the space of the church. Each scene contains a caption in Latin that names the ritual and is later elaborated further by additional text that explains the proper observance of that ritual. Valadés intended for his illustrations to be mnemonic aids, in order to help indigenous peoples remember the proper behaviors and practices of a good Christian. Mnemonic visual structures have the ability to condense text by opening up an image to a full explanation of its importance and meaning, which exists outside of the strict pictorial space of The Image. ${ }^{18}$ Instead of leaving an image open to interpretation by any viewer, which could vary based on the viewer's personal background, the collapsing of text into mnemonic images in the Rhetorica Christiana imposes the very specific interpretation that Valadés intended to convey. Therefore, written text enumerates the companion image beyond its literal representation through an interpretation will be relied on and remembered in future generations, much in the same way that the text in Folio $29 \mathrm{v}$ of the Codex Telleriano-Remensis works to present an account of history that legitimizes Spanish through apparent endorsement by indigenous peoples.

Through the mediation of a European-based textual system., Folio 29V of the Codex Telleriano-Remensis presents a specific account of the past that furthers Spanish imperialistic goals. Since mestizo artists commissioned by the Spanish were familiar with both European and indigenous cultures, the hybrid codices they created were not viewed as incongruous by either the indigenous peoples or the Spanish. Rather, as Dean and Liebsohn observe, "cultural mixing, even if recognized as such, apparently did not prompt comment from indigenous people. Although objects of disparate cultural origins were used daily, the textual record suggests this facet of life was un-notable." ${ }^{19}$ Though the imposition of textual elements onto images in the Codex Telleriano-Remensis shows that the Spanish wanted to legitimize their rule over "New Spain," they did not want to violently stamp out indigenous artistic forms of representation or indigenous culture. Contrary to a strict imperialist idea of conquest, the Spanish consciously chose to adopt and appropriate certain indigenous forms in order to justify their dominance in terms that would be deemed acceptable by both the colonizers and the colonized.

${ }^{18}$ Lina Bolzoni, "Mexican Nature in Diego Valades' Rhetorica Christiana," Studies in the History of Art 69 (2008): 134.

${ }^{19}$ Dean and Liebsohn, 12. 
Bailey, Guavin Alexander. Art of Colonial Latin America. London: Phaidon Press, 2005.

Bolzoni, Lina. "Mexican Nature in Diego Valades' Rhetorica Christiana," Studies in the History of Art 69 (2008): 127-139.

Burlad, C.A. Introduction to Codex Fejérváry-Mayer M 12014. Graz, Austria: Akademische Druck- u. Verlagsanstalt, 1971.

Cummins, Thomas. "From Lies to Truth: Colonial Ekphrasis and the Act of Cross cultural Translation." In Reframing the Renaissance, edited by Claire Farago, 153174. New Haven: Yale University Press, 1995.

Dean, Carolyn, and Dana Liebsohn. "Hybridity and Its Discontents: Considering Visual Culture in Colonial Spanish America." Colonial Latin American Review 12, no. 1 (June 2003): 5-35.

Quiñones Keber, Eloise. Codex Telleriano-Remensis: ritual, divination, and history in a pictorial Aztec manuscript. Austin: University of Texas Press, 1995.

Rabasa, Jose. "The Colonial Divide." Journal of Medieval and Early Modern Studies 37, no. 3 (2007): 511-529.

Valades, Fray Diego de. Rhetorica Christiana. Perugia: apud Petrumiacobum Petrutium, 1579. 